\title{
Correlation between metallothionein (MT) expression and selected prognostic factors in ductal breast cancers
}

\author{
Agnieszka Gomulkiewicz ${ }^{1}$, Marzena Podhorska-Okolow ${ }^{1}$, Rafal Szulc ${ }^{3}$, \\ Zbigniew Smorag ${ }^{3}$, Andrzej Wojnar ${ }^{3}$, Maciej Zabel ${ }^{1,2}$, Piotr Dziegiel ${ }^{1,2,3}$ \\ ${ }^{1}$ Department of Histology and Embryology, Wroclaw Medical University, Wroclaw, Poland \\ 2Department of Histology and Embryology, University of Medical Sciences, Poznan, Poland \\ ${ }^{3}$ Lower Silesian Centre of Oncology, Wroclaw, Poland
}

\begin{abstract}
Our study aimed at examining significance of metallothionein (MT) expression in ductal breast cancers by determination of a relationship between expression of MT protein (MT-1/2) and selected prognostic factors, including grade of histological differentiation $(\mathrm{G})$, expression of Ki-67 proliferative antigen, expression of estrogen receptors (ER) and progesterone receptors (PgR) and expression of HER-2 receptor. Material for the studies involved 54 samples of invasive ductal breast cancer, manifesting malignancy grades of G1-G3. In paraffin sections of examined tumours immunohistochemical reactions were performed using specific antibodies directed to MT, Ki-67, ER, PgR or HER-2. Intensity of MT-specific immunohistochemical reactions was measured using the semiquantitative IRS scale of Remmele. Intensity of colour reactions targeted at Ki-67, ER, PgR was evaluated scoring proportions of positive cells, while HER-2-specific reactions were evaluated in the scale of 0-3 points. The lowest level of MT expression was detected in breast cancer cases of G1 malignancy grade (G1 vs G3 p=0.020). A positive correlation between MT and Ki-67 antigen expression $(\mathrm{r}=0.32$, $\mathrm{p}=0.019)$ was disclosed. Moreover, MT expression exhibited negative correlations with expression of ER $(\mathrm{r}=-0.35, \mathrm{p}=0.008)$ and $\mathrm{PgR}(\mathrm{r}=-$ $0.27, \mathrm{p}=0.046)$. No relationships could be detected between expression of MT and expression of HER-2 ( $r=0.12, p=0.37)$. The obtained results suggest that MT expression might be helpful in prognostic evaluation of ductal breast cancers.
\end{abstract}

Key words: metallothionein, breast cancer

\section{Introduction}

Metallothioneins (MT) represent intracellular proteins of 6-7 kDa molecular weight, widely manifested both in plant and animal kingdom. They consist of 61-68 amino acids, among which around $30 \%$ are cysteine residues $[1,2]$. In humans four classes of the proteins were identified, including MT-1, MT-2, MT-3 and MT4 , containing the total number of ten functional isoforms. Expression of MT-1 and MT-2 manifest variable intensity in all tissues and organs of the body. The highest concentration of the proteins was detected in the liver, pancreas, intestine and kidneys [1]. MT-3 and MT-4 are tissue specific and their expression in normal conditions is manifested, respectively, in neurons of central nervous system and in squamous epithelia of

Correspondence: A. Gomulkiewicz, Dept. of Histology and Embryology, Wroclaw Medical University, Chalubinski Street 6a, 50-368 Wroclaw, Poland; tel.: (+4871) 7841369, Fax.: (+4871) 7840082, e-mail: agom@hist.am.wroc.pl skin and alimentary tract $[2,3]$. MT-coding genes are located on chromosome 16q13, and their expression may be induced by various factors, including heavy metals, hormones, cytokines, growth factors, organic compounds and free radicals [4-7].

The unique property of MT, which significantly determines their role in the body, involves the ability of binding heavy metals ions, such as zinc, copper, mercury, lead or cadmium. MT are responsible, first of all, for maintenance of metal homeostasis and detoxication processes $[2,8,9]$. Reversible binding of zinc ions causes that MT affect activity of several zincdependent proteins and enzymes. In this manner MT control several intracellular processes, including proliferation, apoptosis and cell differentiation [10].

Abbreviations: MT - metallothionein; Ki-67 - proliferative antigen; ER - estrogen receptor; PgR - progesterone receptor; HER-2 - human epidermal growth factor receptor 2; G - grade of histological differentiation; IRS - immuno-reactive score 
Moreover, MT, due to high content of cysteine residues in their molecules exhibit strong anti-oxidative properties. In addition to glutathione and antioxidative enzymes, they constitute one of the principal elements of cell protection against free radicals and effects of oxidative stress $[3,8]$.

Studies performed till now demonstrated augmented synthesis of MT in various tumours of either epithelial or mesenchymatic origin $[3,10,11]$. It is suggested that role of the proteins in carcinogenesis is linked to their involvement in processes of cells proliferation and differentiation $[12,13]$. There have been proposed various mechanisms of MT influence on proliferation of cells and progression of tumours. MT provide a direct source of zinc for enzymes engaged in processes of replication, transcription and proteins biosynthesis, taking place in intensely proliferating neoplastic cells. This has been confirmed not only by elevated level of MT in the region of hyperplasia but also by protein translocation from cytoplasm to cell nucleus at the phase of DNA synthesis (S phase) in proliferating cells $[3,14,15]$. Moreover, in in vitro experiments MT was shown to be capable of controlling zinc ion accessibility and, in this way, of modulating activity of transcription factors, including Sp1 and TFIIA, engaged in cell cycle control $[1,10]$. Interaction with $\mathrm{p} 53$ protein, the product of a suppressor gene, seems to be very important for development of a tumour. MT was demonstrated to be capable of removing zinc ions from p53 protein molecules, leading to changes in their spatial structure and inactivation. This, similarly to mutations within $\mathrm{p} 53$, results in an uncontrolled cell proliferation [16-20]. The other suggested mechanism by which MT may increase proliferative potential of neoplastic cells involves their protection from apoptosis. There was described a specific interaction of MT with $\mathrm{p} 50$ subunit of NF- $\mathrm{KB}$ transcription factor, which results in inhibition of apoptosis [21,22].

Our study aimed at examining significance of MT expression in ductal breast cancers by determination of a relationship between MT protein (MT-1/2) and selected prognostic factors, including grade of histological differentiation $(\mathrm{G})$, expression of Ki-67 proliferative antigen, expression of estrogen receptors (ER) and progesterone receptors (PgR) and expression of HER-2 receptor.

\section{Material and methods}

Tissues. The investigated material included 54 samples of invasive ductal breast cancer, obtained from patients subjected to surgery in the Lower Silesia Centre of Oncology in Wroclaw in 2004-2007. The mean age of the patients was $63.65 \pm 12.84$ years. In each case the diagnosis was confirmed by histopathology. The grade of histological differentiation $(\mathrm{G})$ was estimated according to BloomRichardson scale [23]. The group of studied breast cancers contained highly differentiated tumours $(\mathrm{G} 1)-11$ cases, moderately differentiated tumours (G2) - 27 cases and poorly differentiated tumours (G3) - 16 cases.

Immunohistochemistry. Expression of MT (MT-1/2), Ki-67, ER, PgR and HER-2 was examined immunohistochemically in paraffin sections. Tumour samples were fixed in $10 \%$ buffered formalin, dehydrated and embedded in paraffin. Four-micrometer sections were mounted on Superfrost Plus slides (Menzel Gläser, Germany), dewaxed with xylene and gradually rehydrated. Activity of endogenous peroxidase was blocked using 3\% hydrogen peroxide. Immunohistochemical reactions were performed using specific antibodies: MT-specific monoclonal mouse antibody, clone E9 (DakoCytomation, Denmark) at dilution 1:100, Ki-67-specific monoclonal mouse antibody, clone MIB-1 (DakoCytomation, Denmark) at dilution 1:100, ER-specific monoclonal mouse antibody, clone 1D5 (DakoCytomation, Denmark) at dilution 1:75, PgR-specific monoclonal mouse antibody, clone PgR 636 (DakoCytomation, Denmark) at dilution 1:100. Incubation with the antibodies was conducted overnight, at $4^{\circ} \mathrm{C}$. Except of the MT-specific reaction, in all remaining cases the sections were boiled in Antigen Retrieval Solution (DakoCytomation, Denmark). Following incubation with secondary biotinylated antibodies (Biotinylated Link, DakoCytomation, Denmark), reactions with the streptavidin-biotinylated peroxidase complex (LSAB+ System-HRP, DakoCytomation, Denmark) were performed. The peroxidase substrate of 3,3'-diaminobenzidine (DAB+ Chromogen, DakoCytomation, Denmark) was used as a chromogen. All the sections were counterstained with haematoxylin. Expression of HER-2 was examined using HercepTest ${ }^{\mathrm{TM}}$ kit containing appropriate rabbit polyclonal antibody, according to the procedure recommended by the manufacturer (DakoCytomation, Denmark).

The intensity of MT expression was evaluated using the semiquantitative IRS (immuno-reactive score) scale according to Remmele, which took into account the intensity of the colour reaction and the percentage of positive cells [24]. The final score represented a product of points given for individual traits and ranged between 0 and 12 (Table 1). Expression of Ki-67 antigen, estrogen receptors (ER) and progesterone receptors $(\mathrm{PgR})$ was evaluated scoring percentage of cells manifesting nuclear colour reaction. In every case the appraisal was performed in five representative microscope fields (hot-spots, magnification $\times 200$ ) using the software for computer-assisted image analysis, analySIS 3.2. (Germany). In evaluation of HER-2 receptor expression the scale was employed which took into account intensity and character of membranous colour reaction and percentage of cells manifesting such a reaction [25] (Table 2). Intensity of immunohistochemical reactions was evaluated independently by two pathologists.

Statistical analysis. The obtained results were subjected to statistical analysis using Statistica 7.1 software (StatSoft, Poland). For normality of the distribution the Kolmogorov-Smirnov test was employed. Correlation between expression intensities of selected markers was examined using Spearman rank correlation index. Significance of differences in expression of studied markers was examined using $U$ test of Mann-Whitney. The results were regarded statistically significant at $\mathrm{p}<0.05$.

\section{Results}

Expression of metallothionein (MT) was demonstrated in 53 cases of ductal breast cancer (98.15\%). In all the cases a cytoplasmic or a nuclear-cytoplasmic reaction was noted (Fig. 1A, 1B). Most of the examined tumours manifested different distribution of MT and differences in intensity of the reaction. The mean intensity of reaction in IRS scale was $4.48 \pm 2.72$ pts. 
Table 1. Evaluation of MT expression using IRS scale [24].

\begin{tabular}{|l|c|l|c|}
\hline $\begin{array}{c}\text { Pcrcentage of } \\
\text { positive cells }\end{array}$ & Points & $\begin{array}{c}\text { Intensity of } \\
\text { colour reaction }\end{array}$ & Points \\
\hline No positive cells & 0 & $\begin{array}{l}\text { No colour } \\
\text { reaction }\end{array}$ & 0 \\
\hline$<10 \%$ positive cells & 1 & $\begin{array}{l}\text { Weak colour } \\
\text { reaction }\end{array}$ & 1 \\
\hline $10-50 \%$ positive cells & 2 & $\begin{array}{l}\text { Moderate colour } \\
\text { reaction }\end{array}$ & 2 \\
\hline $51-80 \%$ positive cells & 3 & $\begin{array}{l}\text { Strong colour } \\
\text { reaction }\end{array}$ & 3 \\
\hline$>80 \%$ positive cells & 4 & & \\
\hline
\end{tabular}

Expression of Ki-67 antigen was detected in all studied cases. The colour reaction of a variable intensity manifested the nuclear localization (Fig. 1C). The mean percentage of positive cells was $41.18 \% \pm 25.93 \%$.

Expression of estrogen receptors (ER) was demonstrated in 40 cases (74.07\%) (Fig. 1D). The mean percentage of positive cells was $53.35 \% \pm 40.16 \%$.

Presence of progesterone receptors (PgR) was documented in 37 cases $(68.52 \%)$ (Fig. 1E). The mean percentage of positive cells was $36.85 \% \pm 41.50 \%$.

Expression of HER-2 receptor was detected in 42 cases $(77.78 \%)$. The colour reaction of a variable intensity demonstrated a membranous location (Fig. $1 F)$. The mean intensity of the reaction in the applied scale of appraisal was $1.48 \pm 1.06$ pts.

The lowest expression of MT was found in the highly differentiated breast cancers, G1. In the worse differentiated breast cancer cases, G2 and G3, the level of MT was slightly higher and manifested an increasing trend (G1 vs G3, p=0.020) (Fig. 2).

In order to examine the relationship between expression of MT and other studied markers, Spearman's rank correlation index was used. Results of the analyses demonstrated a moderately positive correlation between expression of MT and Ki-67 antigen $(\mathrm{r}=0.32$, $\mathrm{p}=0.019)$ (Fig. 3). Moreover moderately negative correlations were detected between MT expression and expression of ER receptors $(\mathrm{r}=-0.35$, $\mathrm{p}=0.008)$ (Fig. 4) and $\mathrm{PgR}$ receptors $(\mathrm{r}=-0.27$, $\mathrm{p}=0.046$ ) (Fig. 5). On the other hand, no relationship could be disclosed between MT expression and expression of HER-2 $(r=0.12, p=0.37)$.

\section{Discussion}

The numerous studies performed up to now demonstrated increased MT (MT-1/2) expression in several tumours, including tumours of lungs, ovary, urinary bladder, large intestine and kidneys [26-30]. In most of the cases high level of the protein was linked to poor prognosis. Several authors showed an evident relation-
Table 2. Evaluation of HER-2 receptor expression [25].

\begin{tabular}{|l|c|}
\hline \multicolumn{1}{|c|}{ Intensity of membranous colour reaction } & Points \\
\hline $\begin{array}{l}\text { No colour reaction or weak membranous colour } \\
\text { reaction in }<10 \% \text { cancer cells }\end{array}$ & 0 \\
\hline $\begin{array}{l}\text { Weak membranous colour reaction in }>10 \% \text { cancer } \\
\text { cells, stained fragments of cells membrancs }\end{array}$ & 1 \\
\hline $\begin{array}{l}\text { Weak or moderate staining of the entire cell } \\
\text { membrane, present in }>10 \% \text { cancer cells }\end{array}$ & 2 \\
\hline $\begin{array}{l}\text { Intense, evident staining of the entire cell membrane, } \\
\text { present in }>10 \% \text { cancer cells }\end{array}$ & 3 \\
\hline
\end{tabular}

ship between intensity of MT expression and clinical advancement of the tumours, frequency of metastasis development, as well as shortening of survival rate and disease free survival [17,28,31-34]. In some tumours also a significant correlation between high levels of MT and unfavourable results of treatment was observed [30,35,36].

An increased MT (MT-1/2) expression was demonstrated also in breast cancers, but clinical significance of the proteins has not been yet unequivocally determined. In the normal mammary gland MT expression is noted mainly in myoepithelial cells, while in epithelial cells of ducts MT expression is found very rare [15]. A similar pattern of MT expression was observed in the examined benign lesions of mammary gland, including adenomas, adenofibromas and papillomas [37]. In lobular breast cancers as well as in other, less frequent histological types of the tumour, including mucinous carcinoma and papillary carcinoma, in most cases no MT expression or weak cytoplasmic reactions was shown $[13,15]$. On the other hand, a definitely increased MT expression was noted in ductal breast cancer, both in in situ and invasive forms. According to authors of the till now published reports $26 \%$ to $100 \%$ of all ductal breast cancer cases manifest overexpression of MT [15].

It is suggested that the role of MT in carcinogenesis and tumour progression could be linked to the involvement of MT in processes of cell proliferation and differentiation $[10,12,13]$. Using flow cytometry, the highest concentration of MT was found in cells at the end of G1 phase and at the threshold of G1/S phases [38]. Moreover, a significant MT translocation was immunocytochemically demonstrated to take place from cytoplasm to cell nucleus during $\mathrm{S}$ phase of cell cycle $[3,15]$. In in vitro studies conducted on human breast cancer cell line MCF-7, the inhibition of MT expression by anti-sense oligonucleotides was observed to inhibit cell growth and to activate apoptosis [39]. Disturbances in cell cycle linked to uncontrolled cell proliferation and inhibition of apoptotic process are widely known to represent a significant component of neoplastic progression. The increased 

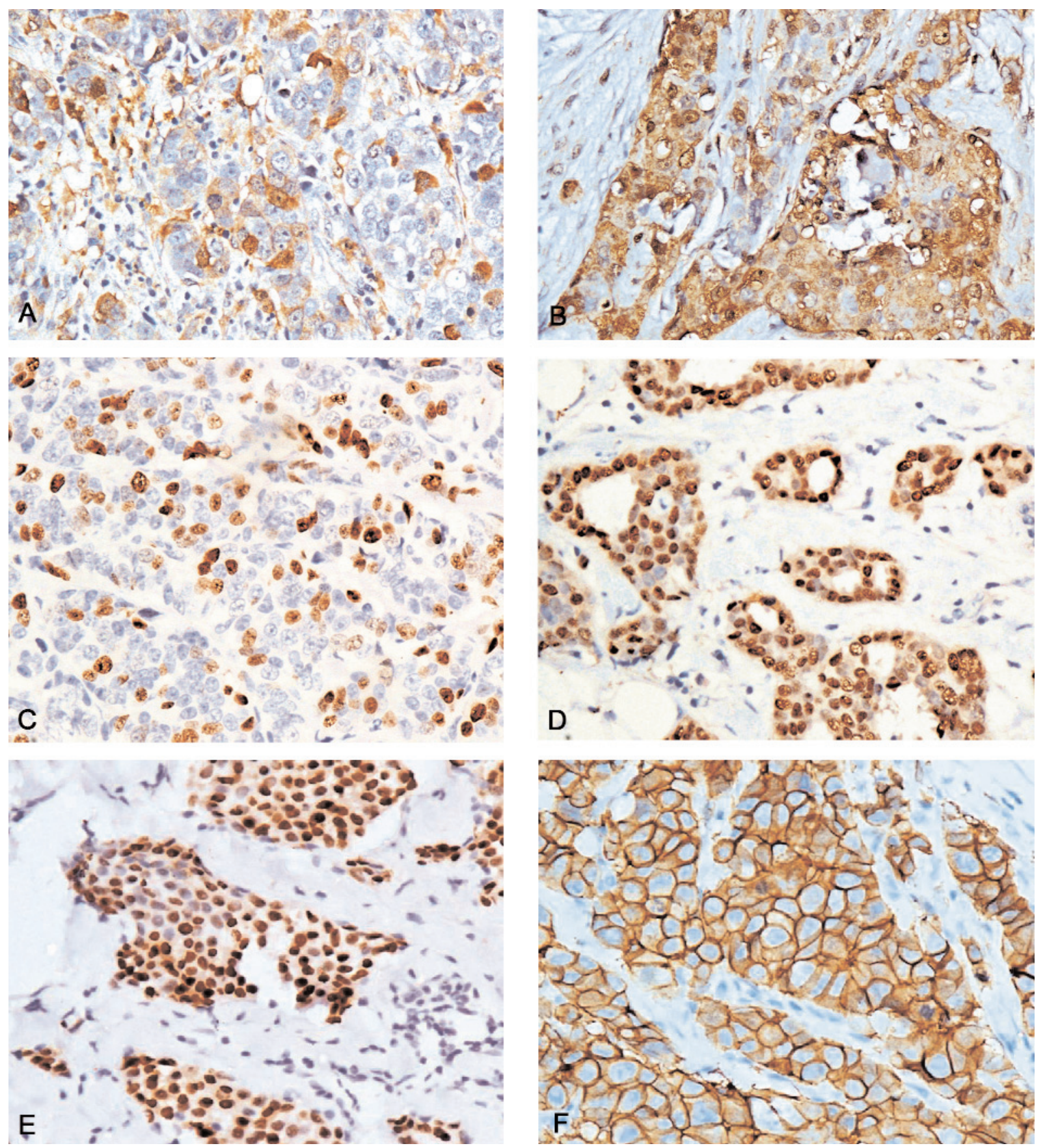

Fig. 1. Expression of studied proteins in cells of ductal breast cancers. MT, a weak nuclear-cytoplasmic reaction (A). MT, moderate nuclearcytoplasmic reaction (B). Ki-67, moderate nuclear reaction (C). ER, strong nuclear reaction (D). PgR, strong nuclear reaction (E). HER-2, strong membranous reaction $(\mathbf{F})$. Immunohistochemical technique, counterstained with hematoxylin (original magnification $\times 200$ ).

proliferative activity results in a more pronounced expansion of the tumour, in accelerated course of the disease and, thus, in worse prognosis.

In our investigations we have evaluated expression of MT (MT-1/2) in cells of ductal breast cancer and its relationship with an increased proliferative potential of neoplastic cells, manifested by expression of Ki-67 antigen. Ki-67 antigen is thought to represent one of the most sensitive indices of cell proliferative activity and numerous till now conducted studies have corrob- orated prognostic value of its expression in various tumours [40]. In the examined cases of invasive ductal breast cancer we have demonstrated a positive correlation between MT and Ki-67 antigen expression, corroborating the earlier results of Jin et al., obtained in the same type of tumour [41]. A similar relationship has been documented, i.a., in squamocellular oesophageal carcinoma, nasopharyngeal carcinoma, as well as in cancers of ovary, large intestine and kidneys $[27,29,30,32,42]$. Positive correlation between MT and 


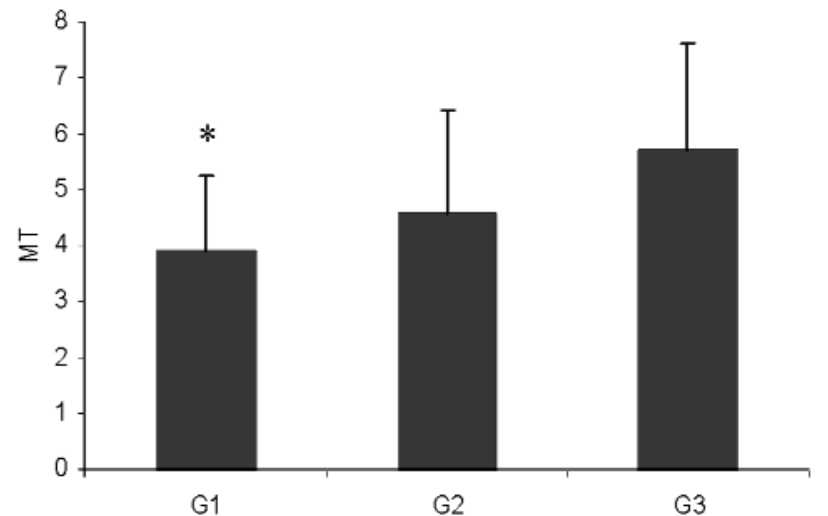

Fig. 2. Intensity of MT expression (IRS) in ductal breast cancers as related to their grade of histological differentiation, G $(* \mathrm{p}=0.020 \mathrm{G} 1$ vs G3).

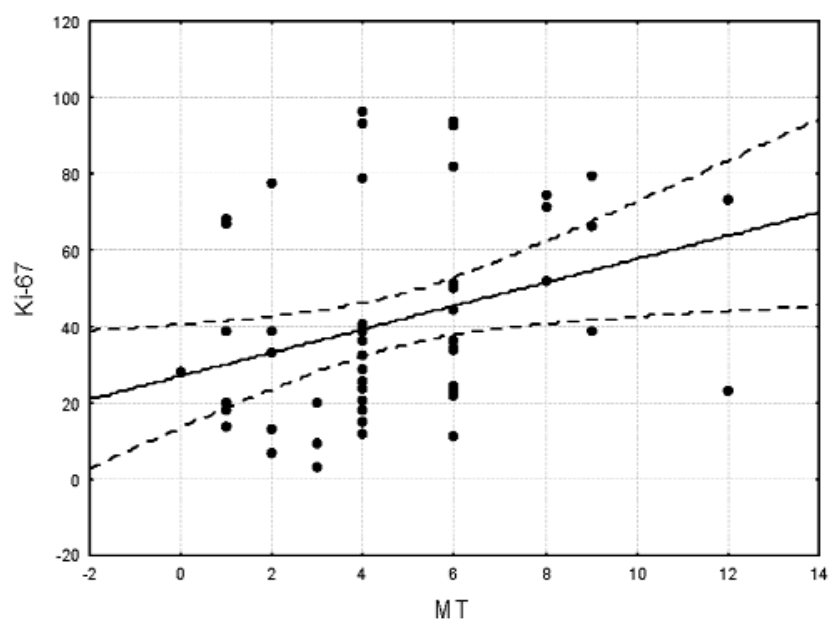

Fig. 3. Correlation between expression of MT (IRS) and expression of Ki-67 antigen (\% cells) in the studied group of ductal breast cancers $(\mathrm{r}=0.32, \mathrm{p}=0.019)$.

Ki-67 expression has been confirmed also in tumours of mesodermal origin, i.e. in histiocytic fibrosarcoma, adiposarcoma and synovial sarcoma [43]. Results of our studies as well as reports of other authors corroborate the hypothesis on involvement of MT in processes linked to cell proliferation.

The involvement of MT in processes of tumour differentiation, proliferation and progression is also indicated by the relationship between expression levels of the proteins and tumour grade of histological differentiation $(\mathrm{G})$. The grade of histological differentiation or, in other words, grade of malignancy is a resultant of three tumour characteristics, including the ability to form glandular structures, polymorphism of cells which form tumour structures and mitotic activity. Jin et al. found that in breast cancer cases of the highest malignancy G3, expression of MT was significantly

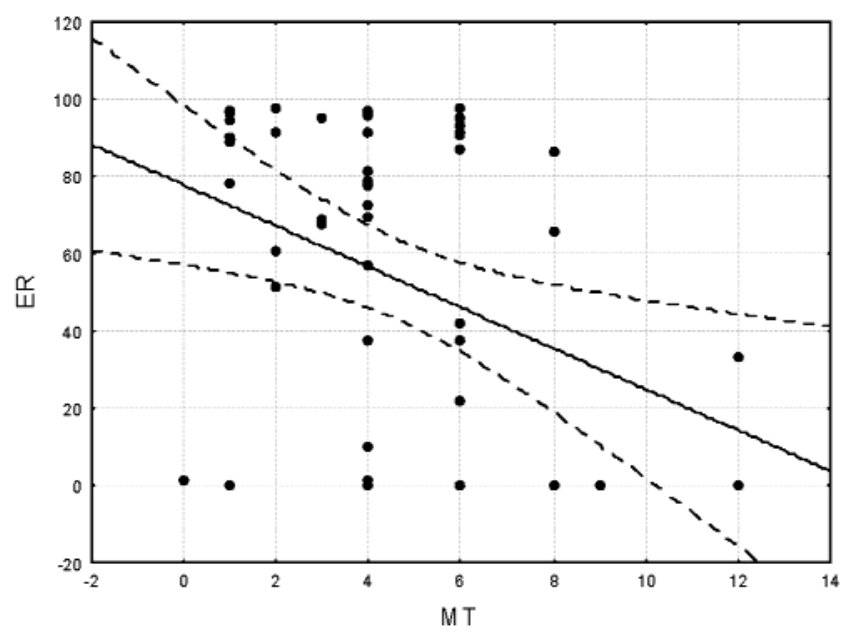

Fig. 4. Correlation between expression of MT (IRS) and expression of ER receptor (\% cells) in the studied group of ductal breast cancers $(\mathrm{r}=-0.35, \mathrm{p}=0.008)$.

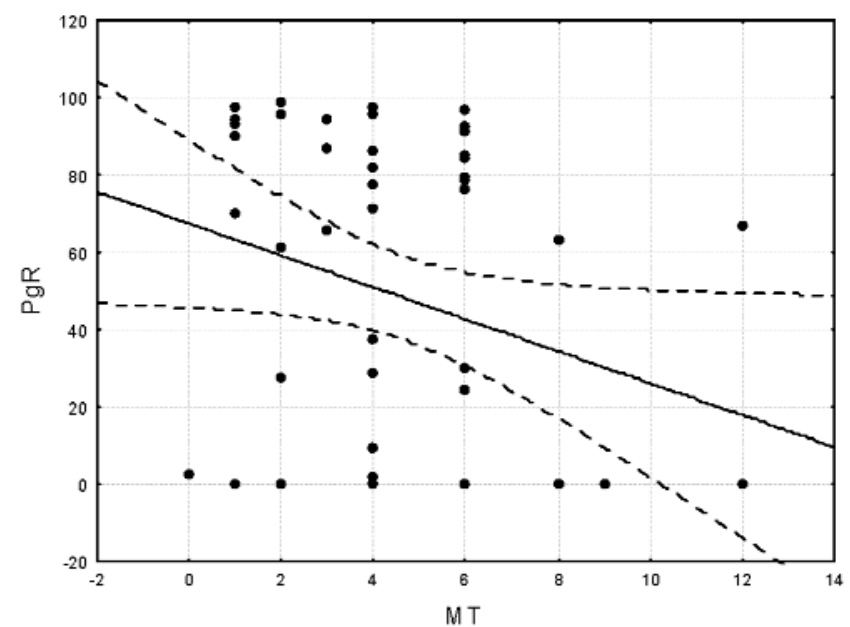

Fig. 5. Correlation between expression of MT (IRS) and expression of PgR receptor (\% cells) in the studied group of ductal breast cancers $(\mathrm{r}=-0.27, \mathrm{p}=0.046)$.

higher than in better differentiated cases, G1 and G2 $[41,44]$. Similar observations were made recently by Yap et al. [36]. In turn, Gallicchio et al. in the studied group of 110 cases of ductal breast cancer demonstrated a strong positive correlation between intensity of MT expression and grade of malignancy [45]. Our results have corroborated results of other authors: we have noted a clearly lower expression of MT in cases of a lower malignancy grade G1, and the expression has increased with increasing grade of cancer malignancy.

Analysis of the obtained results demonstrated also negative correlation between MT expression on one hand and expression of estrogen (ER) and progesterone $(\mathrm{PgR})$ receptors on the other. Presence of ER and $\mathrm{PgR}$ in cells of breast cancer and other hormonedependent tumours, including ovarian and uterine can- 
cers, is linked to a more favourable prognosis. The estrogen-positive cases of mammary cancers have been shown to manifest lower proliferative potential and lower expression of receptors for epidermal growth factors, such as EGFR and HER-2 [46,47]. The increased expression of MT in cases of breast cancers devoid of estrogen and progesterone receptors confirms the unfavourable prognostic significance of the proteins. Results of our studies corroborate reports of other authors. Ioachim et al. observed that in ductal breast cancers MT expression is significantly higher in cases characterized by absence of ER and PgR $[48,49]$. The same authors in endometrial carcinoma showed an evident negative correlation between intensity of MT expression and contents of ER and PgR [50]. In turn, in ovarian cancers no relationship between expression of MT and status of receptors for steroid hormones was demonstrated [27].

On the other hand, in the examined group of ductal breast cancers no relationships could have been detected between expression of MT and HER-2 receptor, belonging to the family of membranous epidermal growth factor receptors (EGFR). Cases of breast cancer with over-expression of HER-2 receptor are characterized by a more aggressive course and less favourable prognosis [25]. In the available references no data could have been noted on relationships between MT and HER-2, which would allow to verify the result obtained in this study.

The conducted studies indicate that pronounced expression of MT protein in ductal breast cancers may represent an unfavourable prognostic index. Results of this report as well as data of other authors suggest a need for continuing studies which will permit to better understand role of MT in the neoplastic process and to define clinical significance of their expression in various types of tumours, including breast cancer.

Acknowledgements: The study was supported by research funds from the Ministry of Science and Higher Education, research project no. N N401 005437.

\section{References}

[1] Coyle P, Philcox JC, Carey LC, Rofe AM. Metallothionein: the multipurpose protein. Cell Mol Sci. 2002;59:627-647.

[2] Vasak M. Advances in metallothionein structure and functions. J Trace Elem Med Biol. 2005;19:13-17.

[3] Theocharis SE, Margeli AP, Klijanienko JT, Kouraklis GP. Metallothionein expression in human neoplasia. Histopathology. 2004;45:103-118.

[4] Miles AT, Hawksworth GM, Beattie JH, Rodilla V. Induction, regulation, degradation and biological significance of mammalian metallothioneins. Crit Rev Biochem Mol Biol. 2000; 35:35-70.

[5] Ghoshal K, Jacob ST. Regulation of metallothionein gene expression. Prog Nucleic Acid Res Mol Biol. 2001;66:357-384.

[6] Saydam N, Adams TK, Steiner F, Schaffner W, Freedman JH. Regulation of metallothionein transcription by the metal- responsive transcription factor MTF-1: identification of signal transduction cascades that control metal inducible transcription. J Biol Chem. 2002;277:20438-20445.

[ 7] Haq F, Mahoney M, Koropatnick J. Signaling events for metallothionein induction. Mutat Res. 2003;533:211-226.

[8] Romero-Isart N, Vasak M. Advances in the structure and chemistry of metallothioneins. J Inorg Biochem. 2002;88: 388-396.

[ 9] Theocharis SE, Margeli AP, Koutselinis A. Metallothionein: a multifunctional protein from toxicity to cancer. Int $J$ Biol Markers. 2003;18:162-169.

[10] Cherian MG, Jayasurya A, Bay BH. Metallothioneins in human tumors and potential roles in carcinogenesis. Mutat Res. 2003;533:201-209.

[11] Dziegiel P. Expression of metallothionein in tumor cells. Pol J Pathol. 2004;55:3-12.

[12] Shimoda R, Achanzar WE, Qu W. Metallothionein is a potential negative regulator of apoptosis. Toxicol Sci. 2003;73:294-300.

[13] Bay BH, Jin R, Huang J, Tan PH. Metallothionein as a prognostic biomarker in breast cancer. Exp Biol Med. 2006;231: 1516-1521.

[14] Cherian MG, Apostolova MD. Nuclear localization of metallothionein during cell proliferation and differentiation. Cell Mol Biol. 2000;46:347-356.

[15] Jin R, Huang J, Tan PH, Bay BH. Clinicopathological significance of metallothioneins in breast cancer. Pathol Oncol Res. 2004;10:74-79.

[16] Meplan C, Richard MJ, Hainaut P. Metalloregulation of the tumor suppressor protein $\mathrm{p} 53$ : zinc mediates the renaturation of p53 after exposure to metal chelators in vitro and in intact cells. Oncogene. 2000;19:5227-5236.

[17] Fan LZ, Cherian MG. Potential role of p53 on metallothionein induction in human epithelial breast cancer cells. $\mathrm{Br} J$ Cancer. 2002;87:1019-1026.

[18] Ostrakhovitch EA, Olsson PE, Jiang S, Cherian MG. Interaction of metallothionein with tumor suppressor p53 protein. FEBS Lett. 2006;580:1235-1238.

[19] Ostrakhovitch EA, Olsson PE, von Hofsten J, Cherian MG. P53 mediated regulation of metallothionein transcription in breast cancer cells. J Cell Biochem. 2007;102:1571-1583.

[20] Cardoso SV, Silveira-Junior JB, De Carvalho Machado V, DePaula AM, Loyla AM, De Aguiar MC. Expression of metallothionein and p53 antigens are correlated in oral squamous cell carcinoma. Anticancer Res. 2009;27:1189-1194.

[21] Abdel-Mageed AB, Agrawal KC. Activation of nuclear factor kappa B: potential role in metallothionein-mediated mitogenic response. Cancer Res. 1998;58:2335-2338.

[22] Kim CH, Kim JH, Lee J, Ahn YS. Zinc-induced NF- $\mathrm{BB}$ inhibition can be modulated by changes in the intracellular metollothionein level. Toxicol Appl Pharmacol. 2003;190:189-196.

[23] Rosen PP. Invasive duct carcinoma: assessment of prognosis, morphologic prognostic markers and tumor growth rate. In: Pine JW, McGough J, ed. Rosen's Breast Pathology. New York: Lippincott Wiliams and Wilkins, a Wolters Kluwer business; 2009:358-404.

[24] Remmele W, Stenger HE. Recommendation for uniform definition of an immunoreactive score (IRS) for immunohistochemical estrogen receptor detection in breast cancer tissue. Pathologe. 1987;8:138-140.

[25] Mueller-Holzner E, Fink V, Frede T, Marth C. Immunohistochemical determination of HER-2 expression in breast cancer from core biopsy specimen: a reliable predictor of HER-2 status of the whole tumor. Breast Cancer Res Treat. 2001;69:13-19.

[26] Joseph MG, Banerjee D, Kocha W, Feld R, Stitt LW, Cherian MG. Metallothionein expression in patients with small cell carcinoma of the lung. Correlation with other molecular markers and clinical outcome. Cancer. 2001;92:836-842. 
[27] Hengstler JG, Pilch H, Schmidt M et al. Metallothionein expression in ovarian cancer in relation to histopathological parameters and molecular markers of prognosis. Int. J. Cancer. 2001;95:121-127.

[28] Saga Y, Hashimoto H, Yachiku S, Tokumitsu M, Kanenko S. Immunohistochemical expression of metallothionein in human bladder cancer: correlation with histopathological parameters and patient survival. J Urol. 2002;168:22272231.

[29] Dziegiel P, Forgacz J, Suder E, Surowiak P, Kornafel J, Zabel M. Prognostic significance of metallothionein expression in correlation with Ki-67 expression in adenocarcinoma of large intestine. Histol Histopathol. 2003;18:401-407.

[30] Mitropoulos D, Kyroudi-Voulgari A, Theocharis S et al. Prognostic significance of metalothionein expression in renal cell carcinoma. World J Surg Oncol. 2005;3:1-7.

[31] Hishikawa Y, Kohno H, Ueda S et al. Expression of metallothionein in colorectal cancers and synchronous liver metastases. Oncology. 2001;61:162-167.

[32] Hishikawa Y, Koji T, Dhar DK, Kinugasa S, Yamaguchi M, Nagasue N. Metallothionein expression correlates with metastatic and proliferative potential in squamous cell carcinoma of the esophagus. Br J Cancer. 1999;81:712-720.

[33] Sutoh I, Koho H, Nakashima Y et al. Concurrent expression of metallothionein, glutathione $\mathrm{S}$ transferase $\pi$ end P-glycoprotein in colorectal cancer. Dis Colon Rectum. 2000;43:221-232.

[34] Cardoso SV, Barbosa HM, Candellori IM. Prognostic impact of metallothionein on oral squamous carcinoma. Virchows Arch. 2002;441:174-178.

[35] Surowiak P, Materna V, Maciejczyk A et al. Nuclear metallothionein expression correlates with cisplatin resistance of ovarian cancer cells and poor clinical outcome. Virchows Arch. 2007;450:279-285.

[36] Yap X, Tan HY, Huang J et al. Over-expression of metallothionein predicts chemoresistance in breast cancer. $J$ Pathol. 2009;217:563-570.

[37] Bier B, Douglas-Jones A, Totsch MI et al. Immunohistochemical demonstration of metallothionein in normal human breast and benign and malignant breast lesions. Breast Cancer Res Treat. 1994;30:213-221.

[38] Nagel WW, Vallee BL. Cell cycle regulation of metallothionein in human colonic cancer cells. Proc Natl Acad Sci. 1995;92:579-583.

[39] Abdel-Mageed AB, Agrawal KC. Antisense down-regulation of metallothionein induces growth arrest and apoptosis in human breast carcinoma cells. Cancer Gene Ther. 1997;4: 199-207.

[40] Dziegiel P, Zabel M. Role of immunohistochemical expression of Ki-67 in adenocarcinoma of large intestine. In: Hayat MA, ed. Handbook of Immunohistochemistry and In Situ Hybrydization of Human Carcinomas. Vol 4. Elsevier; 2006:127-134

[41] Jin R, Chow VTK, Tan PH, Dheen ST, Duan W, Bay BH. Metallothionein 2A expression is associated with cell proliferation in breast cancer. Carcinogenesis. 2002;23:81-86.

[42] Jayasurya A, Bay BH, Yap WM, Tan NG, Tan BKH. Proliferative potential in nasopharyngeal carcinoma: correlations with metallothionein expression and tissue zinc levels. Carcinogenesis. 2000;21:1809-1812.

[43] Dziegiel P, Salwa-Zurawska W, Zurawski J, Wojnar A, Zabel M. Prognostic significance of augmented metallothionein (MT) expression correlated with Ki-67 antigen expression in selected soft tissue sarcomas. Histol Histopathol. 2005;20:83-89.

[44] Jin R, Bay BH, Chow VTK, Tan PH. Metallothionein 1F mRNA expression correlates with histological grade in breast carcinoma. Breast Cancer Res Treat. 2001;66:265-272.

[45] Gallicchio LM, Flaws JA, Fowler BA, Ioffe OB. Metallothionein expression in invasive and in situ breast carcinomas. Cancer Detect Prev. 2005;29:332-337.

[46] Ross JS, Fletcher JA. HER-2/neu (c-erb-B2) gene and protein in breast cancer. Am J Clin Pathol. 1999;112:53-67.

[47] Jensen EV, Cheng G, Palinmieri C et al. Estrogen receptors and proliferation markers in primary and recurrent breast cancer. Proc Natl Acad Sci. 2001;98:15197-15202.

[48] Ioachim E, Kamina S, Demou A, Kontostolis M, Lolis D, Agnantis N. Immunohistochemical localization of metallothionein in human breast cancer in comparison with cathepsin D, stromelysin-1, CD44, extracellular matrix components, $\mathrm{P} 53, \mathrm{Rb}, \mathrm{C}$-erbB-2, EGFR, steroid receptor content and proliferation. Anticancer Res. 1999;19:2133-2140.

[49] Ioachim E, Tsanou E, Briasoulis E et al. Clinicopathological study of the expression of hsp27, pS2, cathepsin D and metallothionein in primary invasive breast cancer. Breast. 2003; 12:111-119.

[50] Ioachim E, Kitsiou E, Carassavoglou C, Stefankaki S, Agnantis NJ. Immunohistochemical localization of metallothionein in endometrial lesions. J Pathol. 2000;191:269-273.

Submitted: 20 August, 2009 Accepted after reviews: 11 March, 2010 